NBER WORKING PAPER SERIES

CAN CENTRAL BANKS TARGET BOND PRICES?

Kenneth N. Kuttner

Working Paper 12454

http://www.nber.org/papers/w12454

NATIONAL BUREAU OF ECONOMIC RESEARCH
1050 Massachusetts Avenue
Cambridge, MA 02138
August 2006

I am grateful to Toshiki Jinushi for helpful discussions; to Ehung Gi Baek, Ben Friedman, Brian Sack and Ellis Tallman for detailed comments on an earlier draft; and to my former colleagues at the Federal Reserve Bank of New York, especially Tony Rodrigues, for ideas that contributed to this paper. The views expressed herein are those of the author(s) and do not necessarily reflect the views of the National Bureau of Economic Research.

(C2006 by Kenneth N. Kuttner. All rights reserved. Short sections of text, not to exceed two paragraphs, may be quoted without explicit permission provided that full credit, including $($ ) notice, is given to the source. 
Can Central Banks Target Bond Prices?

Kenneth N. Kuttner

NBER Working Paper No. 12454

August 2006

JEL No. E43, E58, E63

\begin{abstract}
This paper addresses the possible role of bond prices as operating or intermediate targets for monetary policy. The paper begins with a brief review of the mechanisms through which a central bank could, in theory, influence long-term interest rates, and continues with a brief narrative overview of debt management policies in the U.S., tracing their effects on the maturity distribution of outstanding publicly-held Treasury debt and the composition of the assets held by the Federal Reserve System. The empirical section presents new econometric evidence on the effects of these policies on expected excess holding returns ("term premia"), demonstrating that changes in the Fed's holdings of long-term securities have had statistically significant and economically meaningful effects on the term premia associated with Treasury securities with maturities in the two- to five-year range.
\end{abstract}

Kenneth Kuttner

Oberlin College

Economics Department

10 North Professor Street, Rice Hall

Oberlin, OH 44074

and NBER

kenneth.kuttner@oberlin.edu 


\title{
Can Central Banks Target Bond Prices?
}

\author{
Kenneth N. Kuttner
}

\section{Introduction}

The perennial curse of the policymaker is to have more policy objectives than policy tools. Nowhere is this truer than in central banking, where the monetary authority is, at a minimum, called upon to keep inflation low while stabilizing real output variability. In addition, the central bank is expected to guarantee financial stability, and is often also called upon to manage the exchange rate. The pursuit of all these objectives with a single policy instrument — the short-term nominal interest rate-inevitably presents uncomfortable tradeoffs.

The "instrument shortage" problem becomes especially relevant in low inflation environments, like those experienced in many industrialized countries in recent years. The reasons are fourfold. The most obvious is that, when the zero lower bound (ZLB) on the short-term nominal interest rate is binding, the central bank loses its primary, conventional policy tool. But other issues arise even before the policy rate reaches zero. One is that the possibility of a binding ZLB at some point in the future-and the absence of any alternative policy instruments—could (and should) affect the optimal conduct of policy. ${ }^{1}$ Thus, in assessing the importance of the ZLB, it is important to understand the efficacy of instruments other than the short-term policy rate. In addition, because nearzero interest rates can interfere with certain aspects of the financial system, e.g., by increasing the likelihood of "fails" in the repo market or by suppressing interbank funds trading, central banks bay be loath to lower the short-term interest rate too far. ${ }^{2}$ Finally, at very low rates of interest, the impact of reductions in the short-term interest rate on the longer term interest rates relevant for policy transmission may be attenuated by the “optionality” inherent in those long-term rates, a point first noted by Black (1995).

In light of these complications, it is not surprising that central banks have over the years sought additional independent, or quasi-independent, policy instruments. The most

\footnotetext{
${ }^{1}$ This point has been made in a number of studies, such as Orphanides and Wieland (2000).

${ }^{2}$ These concerns raised by economists and policymakers at the Bank of Japan. For a discussion of some of these issues, see Baba et al. (2005), pp. 82-92.
} 
obvious of these is, of course, the exchange rate; McCallum (2000) and Svensson (2003) have forcefully made the case for exchange rate management or outright targeting in a low inflation environment. The objective of these proposals is to cause an expansionary depreciation of the currency, either through aggressive foreign exchange intervention, or with a commitment to a crawling peg. (The latter, as Svensson emphasizes, would also have the advantage in a deflationary environment of raising inflation expectations).

It is fair to say that the possibility of central bank intervention in the bond market has received much less attention in recent years than proposals designed to influence the exchange rate. In fact, the idea of intentionally using Fed policy to raise or lower bond yields had been ignored almost completely until Bernanke (2002) proposed operations involving long-dated Treasury securities as a means of dealing with the threat of deflation. As it turns out, the U.S. economy's recovery, which was already officially under way when Bernanke made his proposal, obviated the need for this sort of "unconventional” monetary policy. Nonetheless, Bernanke's remarks are a reminder that targeting — or at least managing-long-term interest rates is another possible tactic for the implementation of monetary policy.

Indeed, there is a rich earlier literature discussing the ways in which monetary and debt management policies might affect long-term interest rates, and how these policies might be designed to further macroeconomic objectives. Tobin (1963), for one, envisioned an active coordination between monetary and debt management policies, arguing that "The government—comprising both the Federal Reserve and the Treasury — should continuously adjust the maturity structure of the debt, seeking to minimize its net cost, while achieving the required restraint on aggregate demand” (p. 211). ${ }^{3}$ This view pervaded policymaking in the 1950s and 1960s; in fact, according to Volcker (2002), during this period "debt management was considered to be an active 'third leg' of policy.” Tobin's perspective on monetary policy and debt management has been revived in a recent paper by Andrés et al. (2004), who construct a general equilibrium model in which the changes in the relative supplies of outstanding debt constitute a distinct—and

\footnotetext{
${ }^{3}$ Rolph (1957) proposed a criterion for optimal debt management very similar to Tobin’s, namely minimizing the cost of debt service while creating the desired level of monetary stimulus or restraint. Roley (1979) formalized Tobin’s principles using mean-variance portfolio theory.
} 
potentially important—channel for the transmission of monetary policy, via their effects on long-term bond yields.

This paper takes up in detail the possible role of the bond market in monetary policy, raising the question of whether bond prices (or alternatively, yields) could serve as useful operating or intermediate targets for monetary policy-and if so, how such a policy might work. Section 2 contains a brief review of the mechanisms through which a central bank could, in theory, influence long-term interest rates. Section 3 provides a selective narrative overview of debt management policies in the U.S., tracing their effects on the maturity distribution of outstanding publicly-held Treasury debt and the composition of the assets held by the Federal Reserve System. Section 4 presents new econometric evidence on the effects of these policies on expected excess holding returns (“term premia”). The results confirm the findings of Modigliani and Sutch (1967), among others, who found that the composition of privately-held debt in the aggregate has only small and statistically insignificant effects on term premia. Changes in the Fed's holdings of long-term securities, on the other hand, do have statistically significant and economically meaningful effects on term premia. A likely explanation for this result is that changes in the Fed's portfolio are “more exogenous” with respect to term premia than changes the overall volume of privately-held government debt, which includes the (potentially endogenous) issuance of new Treasury securities. The fifth section concludes with a short discussion of the results' implications for monetary policy.

\section{How could central banks affect bond prices?}

It is useful to distinguish between three distinct mechanisms that the central bank might employ in influencing longer-term bond yields: making announcements with the intention of managing expectations of future short-term interest rates (i.e., "open mouth operations”), imposing explicit pegs or ceilings on bond yields, and using open market operations in longer-term securities to affect the relative volume of long-term debt in the hands of private-sector investors.

\section{Open mouth operations and bond price pegs}

The first two mechanisms — open market operations and explicit pegs—are easy to understand within the framework of the expectations hypothesis $(\mathrm{EH})$ of the term 
structure of interest rates. According to the $\mathrm{EH}$, the bond yield represents an average of current and expected future interest rates, plus a constant term premium associated with the specific maturity. Therefore anything the central bank can do to affect expectations of future monetary policy (i.e., short-term interest rates) should be able to influence longterm bond yields. This is consistent with the theoretical work of Eggertsson and Woodford (2003), and underlies the "policy duration effect" of Fujiki and Shiratsuka (2002) and Okina and Shiratsuka (2004). Although less explicit, it may also reflect the FOMC's collective thinking when the committee introduced the "considerable period of time” phrase into the FOMC statement in 2003.

Nor is it any mystery why, under the EH, a credible interest rate peg or cap would be effective. If the central bank were willing to commit to buy and sell bonds at various points along the yield curve (as it did between 1942 and 1951), it could engineer any desired pattern of yields. (This period of interest rate "caps" is discussed in greater detail below, in section 3.) Not only would such a policy tend to reduce interest rates by virtue of its effect on expected future yields, but to the extent that it eliminated any risk from holding long-term bonds, it would also tend to reduce risk or term premiums associated with those maturities. And an interest rate cap—as opposed to a peg-could be even more effective, as it essentially gives the bondholder a free put option: the bondholder enjoys the capital gains from any decline in interest rates, while her downside risk is truncated by the central banks' guarantee of a given minimum bond price. Consequently, bond yields would tend to be slightly lower than any caps that might be imposed by the central bank.

These two strategies both present serious difficulties, however; and as a result, central banks have been very reluctant to use them, except in highly unusual situations. As recent experience has demonstrated, reliably influencing bond prices through open mouth operations is harder than it sounds: in the absence of a commitment to a reasonably specific and explicit path of short-term interest rates (like that of the Bank of Japan in its post-2001 zero interest rate policy), the central bank's efforts to communicate its intentions can be easily misinterpreted—and sometimes backfire. ${ }^{4}$ Besides, some—

\footnotetext{
${ }^{4}$ A vivid example of just such a miscue occurred in August 2003, when the Fed was perceived to back away from an aggressive commitment to maintain low long-term interest rates. "I've lost all faith and
} 
notably Friedman (2003) — have objected to such expectations management strategies, arguing that expectations are shaped by the central bank’s actions, and thus do not represent a distinct policy instrument.

Explicit interest rate targets, caps or pegs present even more serious difficulties than those encountered in the context of open mouth operations. One issue is the "exit strategy" problem: how to discontinue the policy, when the mere hint of its abandonment could lead to the equivalent of a speculative attack. Unlike an exchange rate target, the feasibility of a defense of the target is not an issue-the central bank can always issue any volume of liabilities (i.e., reserves and cash) it likes in order to finance the purchase of long-term government bonds. Doing so would, presumably, drive the short-term interest rate to zero or near-zero levels. And although this may be consistent with a "quantitative easing” policy intended to greatly increase liquidity in the financial system, it would be problematic if the central bank were attempting to pursue the policy in a low (but nonzero) interest rate environment. Thus, a long-term interest rate peg would not be truly independent of the expected path of the short-term interest rate. As discussed below in section 3, the Fed's experience in the pre-Accord period provides an excellent illustration of the inevitable tensions between a short-term interest rate target and an explicit longterm interest rate peg.

\section{Using debt management to influence bond prices}

In light of the complications inherent in both of these strategies, the third optionopen market operations in long-term bonds - is an attractive alternative. Presumably this could be done in the absence of any explicit objective for the bond price (or yield), and with no commitment to any particular path of future interest rates. The scope for a central bank to carry out such a policy is of course limited only by the size of the portfolio of government securities it holds: in principle, aside from a certain buffer stock of short-term securities held to provide liquidity, the central bank could hold all of its assets as long-term bonds-or none at all. In practice, the U.S. Federal Reserve in recent years has tended to hold over half of its assets as short-term securities with less than 12

confidence in the Fed," one bond trader was quoted as saying. "If the Fed was hoping to keep interest rates low, it’s backfired.” See Hays (2003). 
months to maturity ( $\$ 400$ billion out of a total of $\$ 744$ billion, as of December 2005), as shown in Table 1. (While this category includes some longer-term notes or bonds that are close to maturity, the vast majority consists of bills.) Just over one-quarter (\$211 billion) are in the one- to five-year category, while the remaining 18 percent is split between the five- to ten-year ( $\$ 57$ billion) and over ten-year ( $\$ 77$ billion) categories. Thus, there would considerable scope for the Fed to increase its holdings of these longer maturities: a $\$ 300$ billion reallocation from bills to notes and bonds is clearly feasible, and would still leave $\$ 100$ billion invested in short-term bills.

There is no question that such a reallocation would have a massive impact on the Fed's portfolio-but what presumably matters for bond yields would be the volume of long-term securities left in the hands of investors other than the Fed. As reported in Table 1, the volume of marketable, privately-held Treasuries with maturities in excess of 5 years currently stands at roughly $\$ 1$ trillion. So while the Fed would not be able to purchase all outstanding Federal debt in this maturity range, a $\$ 300$ billion purchase would obviously make a significant dent.

Moreover, the size of the Fed's balance sheet imposes no real constraint on the ability of the U.S. government, broadly defined, to affect the maturity distribution of outstanding, privately-held Federal debt: the Treasury, if chose to do so, could alter the maturity structure of the debt it offered for sale-or even engage in buybacks, as it did from 2000 through 2002, intended to shift the maturity distribution. Thus the Treasury, if it chose to do so, could use debt management in the pursuit of the macroeconomic objectives traditionally assigned to monetary policy.

The crucial issue, of course, is not the potential scope for a central bank-either alone, or in cooperation with the central government - to affect the maturity distribution of outstanding government debt; clearly, it can. Instead, the issue is the extent to which such operations can, in the absence of an explicit target or commitment to a path of shortterm interest rates, have a tangible impact on long-term bond rates.

In a world in which the expectations hypothesis of the term structure determined bond yields, altering the maturity distribution of public debt would have no impact on long-term interest rates: expectations, not relative supplies, would determine the shape of the yield curve. In this case, because the yield on long-term bonds embodied only 
expectations of future interest rates, it could not be thought of as policy instrument that was distinct from the short-term interest rates, and its anticipated trajectory. ${ }^{5}$

As an empirical matter, the expectations hypothesis is not a particularly good theory of bond yields, however. While clearly useful as a benchmark for understanding the contribution of interest rate expectations in bond yields, the EH has earned the distinction of one of the most consistently rejected economic theories in the literature. Still, in order to argue for a role for relative asset quantities, it is necessary to go beyond the rejection of the EH. In essence, for relative bond supply to affect bond yields requires something that could be described as a downward sloping "bond demand" curve; this, in turn means that long-term bonds must be imperfect substitutes for bonds of other maturities.

This hypothesis of imperfect substitutability has long been understood as the critical ingredient in any theory allowing for effects of asset supplies on bond yields, such Tobin’s (1969) general equilibrium theory incorporating financial markets and the macroeconomy. In his framework, the effects of monetary policy are not captured in any single variable - and, because of the ways in which other factors, including asset supplies, affect relative asset returns, no single variable completely captures the "stance" of monetary policy.

The difficulty in this approach has always been to formalize in a satisfactory way the microeconomics underlying imperfect substitutability across assets. While empirical implementations, such as that of Backus et al. (1980), often relied on arbitrarily-specified demand functions, efforts were made to derive an asset demand system from an explicit portfolio optimization problem. Building on Tobin's insight that the substitutability between alternative assets depended on the covariance between those assets' returns, Roley (1979) and Friedman and Roley (1987) showed that, in a static mean-variance setting, an investor's optimal portfolio shares were linearly related to excess returns, via a matrix involving the inverse of the returns’ covariance matrix. Imposing market

\footnotetext{
${ }^{5}$ A parallel issue arises in the context of discussions of whether the exchange rate is a valid objective for monetary policy, independent of the interest rate. In a world characterized by uncovered interest rate parity, the exchange rate is inextricably connected to the short-term interest rate; whereas in a world characterized by portfolio balance effects, some scope would exist for independent management of the rate, in effect through sterilized interventions. The exchange between McCallum (2000) and Christiano (2000) is especially revealing on this point.
} 
equilibrium and inverting this relationship then yields an expression for yields as a function of asset supplies. ${ }^{6}$

Andrés et al. (2004) took a rather different approach to formalizing Tobin’s imperfect substitutability hypothesis. That paper added time-varying, stochastic transactions costs in the bond market as a way to model the illiquidity of long-term bonds, relative to short-term securities. It also introduced heterogeneous agents: some trade both short- and long-term bonds, while others trade only long-term bonds. Together, the liquidity premia generated by the transactions costs, along with the limited participation or "habitat” assumption generate "Tobinesque” results in which monetary policy has real effects through relative asset prices.

\section{A brief history of U.S. debt management since 1941}

Debt management policy_broadly defined to include the Federal Reserve's portfolio management decisions - has gone through a number of distinct phases since WWII, some with dramatic consequences for the structure of outstanding debt and the composition of the Fed's portfolio. Figure 1 shows the average time to maturity (in months) of privately-held Federal debt, and the Treasury securities held by the Federal Reserve System in its System Open Market Account (SOMA). ${ }^{7}$ Figure 2 and Figure 3 display the maturity distribution of the Treasury's outstandings and the Fed's holdings, respectively, broken down into three groups: short-term debt with maturities less than one year, debt with one to five years to maturity, and long-term debt with at least five years to maturity.

The pre-Accord interest rate caps

The first and most volatile period in U.S. debt management (at least post-1941) is the 1942-1951 episode, when the Fed and the Treasury jointly imposed caps on interest

\footnotetext{
${ }^{6}$ While formally a general equilibrium analysis, there is no scope for supply or quantity effects in models like that of Lucas (1978), in which assets are in zero net supply and consumption in each period is equal to an exogenous endowment.

${ }^{7}$ The Treasury data on the maturity distribution of privately-held public debt are reported in Table FD-5 of the Treasury Bulletin, and available post-1975 through Haver Analytics; pre-1975 data were obtained from the Federal Reserve's Annual Statistical Digest, and Banking and Monetary Statistics. The maturity distribution of the SOMA portfolio is reported in Table 1.19 of the Statistical Supplement to the Federal Reserve Bulletin. Historical data were obtained from the Federal Reserve's Annual Statistical Digest, and Banking and Monetary Statistics.
} 
rates-a policy which required extreme adjustments in the Fed's holdings of Treasury securities shown in Figures 1 and 3. Indeed, the Fed's portfolio choices during this period were almost completely driven by its mandate to defend the interest rate caps.

While the origin of the policy to cap long-term interest rate caps is complex, it is clear that the caps were never intended to serve as a tool of monetary policy. ${ }^{8}$ Instead, the caps grew out of the Treasury's concern with minimizing the costs of financing its rapidly-growing debt. Rather than simply monetize the debt, the Fed and the Treasury in March 1942 agreed to target yields at various points along the yield curve: the bill rate would be pegged at 3/8\% using a standing facility, while caps for the 1-year, 7-9 year, and long-bond yields were set at $7 / 8 \%, 2 \%$, and $2 \frac{1}{2} \%$, respectively. ${ }^{9}$ Interestingly, the caps were never explicitly announced, and as a result a number of months passed before the policy became fully understood by market participants.

As the policy became known during the course of 1942 and 1943, it became clear that the pattern of interest rates being set was not consistent with market expectations. Specifically, the indefinite peg of the bill rate at 3/8\% implied levels of medium- and long-term interest rates that were considerably below the interest rate caps enforced by the Fed. However, the caps (to the extent that they were expected to continue into the future) did reduce or eliminate entirely the downside price risk associated with long-term bonds. This presumably made investors much more willing to hold these bonds, as opposed to short-term Treasury bills; indeed, there was little incentive to purchase bills yielding 3/8\% when bonds with a 2-1/2\% coupon yield (and minimal downside price risk) were being sold at par as part of the "Victory Loan” campaigns [see Walker (1954)].

As a result, investors liquidated their holdings of short-term bills, and began buying instead the long-dated, higher-yielding Treasuries; this in turn required that the Fed sell off its portfolio of long-term Treasuries, and purchase bills, in order to maintain

\footnotetext{
8 This paper's brief sketch cannot do justice to this complex and tumultuous period in the Fed's history. Meltzer (2004) provides a comprehensive background, while Chandler (1949) gives a very clear contemporary account. Wicker (1969) discusses the origin of the policy in greater detail, focusing on the disputes between the Fed and the Treasury. Toma (1992) addresses the inflationary implications of the policy, while Eichengreen and Garber (1991) interprets the interest rate peg in terms of a price level target zone.

${ }^{9}$ Fed officials were uncomfortable with pegging the short end of the yield curve at such a low level, however, and during the course of the war it repeatedly asked the Treasury for permission to raise the bill rate.
} 
the bill rate at 3/8\%. Consequently, the Fed's portfolio of bills outstanding jumped to over $\$ 23$ billion, from $\$ 2$ billion, by the end of the war-at which time the Fed held 30\% of all outstanding bills. The average maturity of the Fed's portfolio plunged to only 6 months, as its holdings of long bonds fell to a mere $\$ 708$ million. Interestingly, the caps themselves were binding for only a portion of this period: once the pressures of war finance abated in the spring of 1945, the long bond yield fell below $2 \frac{1}{2} \%$ and remained near 2\% until 1947.

The situation changed abruptly in July 1947 with the abandonment of the 3/8\% peg of the Treasury bill rate, which caused the 90-day yield to rise to near $1 \%$. Suddenly, a $2 \%$ (or even $2 \frac{1}{2} \%$ ) long bond yield looked very low; and investors rushed to exchange bonds for more attractive bills. The Fed was therefore obliged to buy large quantities of the bonds in order to defend the cap, with purchases of $\$ 2$ billion in November and December 1947, and $\$ 3$ billion in the first quarter of 1948. By the end of 1948, the Fed's bond holdings rose from less than $\$ 1$ billion to roughly $\$ 11$ billion, going from a negligible portion of the Fed's portfolio to nearly $40 \% .{ }^{10}$ Most of these purchases were sterilized (i.e., offset with sales of other maturities), leaving the total size of the Fed's portfolio, and bank reserves, unchanged.

The softening economy in late 1948 and 1949 reduced the upward pressure on interest rates, and gave the Fed a brief respite from its defense of the bond yield caps. But as inflation and short-term interest rates rose again in 1950, it became increasingly clear that the interest rate caps were a binding constraint on monetary policy. The Fed made some effort to defend the rate caps during this period, again rapidly accumulating longer-dated securities. (The caps on the intermediate maturities came under the most intense pressure, obliging the Fed to sell both bills and bonds; as a result, the average maturity actually fell during this period.) With most of its portfolio already in notes and bonds, however, very little scope remained for the Fed to defend the caps without expanding the size of its portfolio and increasing bank reserves. In March 1951, with the bond rate at $2.47 \%$, the Fed and the Treasury negotiated the Accord that ended the direct

\footnotetext{
${ }^{10}$ It was at this point that doubts began to arise about the caps' credibility; in fact, in late 1947 and early 1948, Federal Reserve officials found themselves in a position of having to publicly reaffirm the continuation of the $2-1 / 2 \%$ cap for the foreseeable future; see Chandler (1949), pp. 413-414.
} 
setting of long-term interest rates; and in April, the 21/2\% cap on long-term bond yields was breached, marking an end to the Fed's experiment with the direct targeting of longerterm interest rates.

Although they were never intended as a means to further the objectives of monetary policy, the pre-Accord interest rate caps offer a number of important lessons on the scope for-and limitations of — bond prices as explicit policy targets. On the surface, the experience with rate caps suggests that the direct targeting of longer-term rates is possible, at least for a time. Furthermore, it is likely that, even when they did not bind, the interest rate caps may have reduced long-term interest rates, effectively by making the bonds "put-able" at a price corresponding to the yield cap. But the experience also vividly demonstrates that such caps are only feasible to the extent that they are consistent with the expected path of short-term interest rates; after macroeconomic fundamentals shifted to a point where higher short-term rates were expected, the caps were effectively attacked-leaving the Fed in the untenable position of being unable to defend the caps without vastly increasing the size of its balance sheet, and greatly expanding reserves.

\section{Bills Only}

The 1942-51 experience with pegging long-term interest rates left its imprint on the Fed for years to come. The Accord of 1951, which firmly established the Fed's independence from the Treasury, is of course the best-known legacy. But the period of interest rate caps also led indirectly to the Fed's "Bills Only" doctrine, which committed the Fed to dealing almost exclusively in short-term securities.

The Bills Only policy grew out of Fed chairman William McChesney Martin's conviction that the interest rate caps had suppressed the free functioning of the bond market. Martin believed that restoring the proper function of the bond market required convincing dealers that the Fed would not intervene in the future. By limiting its open market operations to bills, the Fed would effectively "tie its hands", and commit to not intervening in the bond market. Martin organized a subcommittee of the FOMC, which recommended such a constraint on the Fed's operations; opposing Martin and his subcommittee was New York Fed president Allan Sproul, who favored leaving the New 
York bank with the flexibility to conduct operations as it saw fit, presumably with an eye to maintaining "orderly conditions" in the bond market, as mandated by the Accord.

In the end, Martin prevailed: in 1953, the FOMC adopted the Bills Only policy, thus removing any scope for debt management efforts on the part of the central bank. ${ }^{11}$ Subsequent events may have prompted second thoughts among Fed officials about its newly-minted policy: in the second quarter of 1953 , the Treasury issued nearly $\$ 5$ billion in 30-year bonds - a significant addition to the existing stock of less than $\$ 23$ billion. As recounted by Volcker (2002), the Treasury's aggressive issuance left the bond market "disturbed," and some believed that this was a contributing factor to the recession that began in July 1953. The Fed's role in managing, if not targeting, long-term interest rates consequently remained a hotly-debated topic for years to come.

\section{Operation Twist}

The next well-defined episode in postwar U.S. debt management is the initiative that came to be known as "Operation Twist." The episode is not interesting for what it did, which, as it turns out, was insubstantial. But it nonetheless remains a salient episode for two reasons: one is that it the only instance in which debt management was used with the stated intention of achieving specific macroeconomic objectives. And second, the evidence (or lack thereof) for the operation's effects on bond yields is, even 45 years later, cited as demonstrating such operations' ineffectiveness.

The ostensible purpose of Operation Twist was to raise short-term interest rates in an effort to stem capital outflows, while minimizing any rise—or even reducing—-longerterm interest rates. In order to accomplish this, the Fed publicly abandoned the Bills Only policy it had adopted eight years earlier: on February 20, 1961, it announced its intention to purchase notes and bonds of various maturities, including some in excess of five years. ${ }^{12}$ The 1961 Economic Report of the President stated (p. 88) that the Fed's purchases of government securities of maturity more than one year amounted to \$2.6

\footnotetext{
11 This account draws on Bremner (2004), pp. 99-103.

${ }^{12}$ Besides altering the maturity structure of government debt, Operation Twist also entailed the relaxation of Regulation Q interest rate ceilings.
} 
billion during that year; the Report also noted that Treasury reportedly purchased an unspecified volume of long-term bonds for its investment accounts.

The effects of Operation Twist on the volume of outstanding long-term notes and bonds turned out to be insignificant, however. As shown in Figure 1, the change in the average maturity of the Fed's portfolio during this period is so small as to be nearly indistinguishable from the normal fluctuations in the series. ${ }^{13}$ A $\$ 5$ billion purchase of notes in late 1960 - before the commencement of Operation Twist—brought the average maturity of the Fed's portfolio to 23 from 17 months; subsequent purchases under Operation Twist only increased the average maturity to 28 months in September, before falling again to 23 months in November and remaining in the 25-month range until mid1965. The Fed's purchases of long-term debt show up slightly more clearly in Figure 2, with a small but distinct increase from 5 to 9 percent of the SOMA portfolio. Meanwhile, the average maturity of privately-held Treasury debt, which stood at 59 months in early 1961, edged up to 62 months by mid-1965 as the Treasury increased its issuance of notes in the 5-10 year range. Tobin (1972) summed up the experience with the remark, "There probably wasn't much in it, but it was never really tried” (p. 32). Despite its prominence in the literature, Operation Twist is therefore a poor test case for the effects of debt management on bond yields.

\section{The 1968-69 maturity bulge}

Heavy borrowing requirements led the Treasury to undertake three massive (by 1960s standards) 6- and 7-year note issues during the 1968-69 period, structured in such a way as to allow holders of maturing notes to exchange them for the new issues. (With the highest coupons since the Civil War, the "sexy sixes" of May 1968 were considered big news at the time.) The Fed was a major holder of the maturing notes, and consequently it absorbed a large proportion of the new Treasury issues; in fact, because the Fed took such a large volume of the notes, the effect on the maturity distribution of publicly-held debt was scarcely noticeable. (The Fed sold off most of its accumulated notes the following year.)

\footnotetext{
${ }^{13}$ While the date of the commencement of Operation Twist is clear, determining the date of its termination is more difficult. The discussion here follows Modigliani and Sutch (1967) in focusing on the period through mid-1965.
} 
Interestingly, the Fed's 1968 note purchases seem not to have been viewed as part of any overt debt management policy—neither contemporary press accounts nor the Fed's Annual Reports make any mention of it. However, by preventing what would otherwise have been a nontrivial lengthening of the maturity of outstanding Treasury debt, the Fed's actions represented a far more significant departure from the Bills Only policy than Operation Twist. ${ }^{14}$

\section{Debt management from the 1970s to 2000}

Debt management policy settled down in the mid-1970s, relative to the 1950s and 1960s, with no pronounced shifts in the debt structure of either the Treasury or the Fed. As shown in Figure 1, the average maturity of the Fed's portfolio typically mirrored the maturity distribution of Treasury debt—rising as the Treasury issued more long-term debt in the latter halves of the 1970s and 1990s. The 1980s represent a notable exception to this pattern however, with the Fed reducing the average maturity of its portfolio even as the Treasury steadily increased the maturity of its outstanding debt by about 20 months, from 48 to 68.

The end of the long bond in 2000

Faced with large budget surpluses, Treasury Secretary Lawrence Summers announced on January 13, 2000 that the Treasury would buy back as much as $\$ 30$ billion in long-term bonds. The purchases, which were to commence later that year, were to target older, high-yielding securities; by concentrating its debt in a smaller number of more widely-traded issues, Treasury officials hoped to reduce the overall cost of debt service. The shaded bars in Figure 4 depict the net change in the supply of bonds from 1998 through early 2002_including the regular new issues through early 2000, followed by the buybacks that began in March. The January announcement was accompanied by a sharp drop in the 30-year to 10-year spread, and the buybacks initially appeared to further depress the 30-year yield, to the point where the 30-year bond yield was below that of the 10-year note. However, despite continued buybacks, the spread moved back into positive

\footnotetext{
${ }^{14}$ A plausible conjecture is that Fed officials wished to avoid the same kind of disruption to the bond market that occurred in 1953, when the Fed, following its Bills Only policy, sat on the sidelines as the Treasury issued a large volume of long-term debt.
} 
territory later in the year, and actually rose to as high as 80 basis points - well above its 1998 peak. The spread fell again on October 30, 2000, when the Treasury announced it would stop issuing 30-year bonds altogether. Overall, the experience suggests that the supply of bonds does affect the relevant yields_although the effect may be transitory. Still, the 2000 episode does not represent an entirely “clean” experiment: while the decrease in bond supply over some range would plausibly have been expected to reduce its yield, at some point the thinning volume of trades may have introduced a liquidity premium, similar to that observed in off-the-run issues.

\section{Econometrically assessing the effects of bond supply}

This section addresses the question of how to assess the effects, if any, of changes in the composition of government debt on bond yields. This is not the first paper to do so, of course; a great deal of research has sought to uncover evidence of "supply effects" on bond yields, with mixed results. To put this paper's results, and its methods, in context, the section begins with a brief review of previous efforts to detect such effects.

\section{A brief review of previous efforts}

The best-known efforts to detect quantity effects in the term structure are those of Modigliani and Sutch (1966; 1967). Their method involved looking at the spread between the yield to maturity of an $n$-period bond and that of a one-period bond; according to the expectations hypothesis, the spread should be related to the expected appreciation (or depreciation) of the $n$-period bond. With a distributed lag on past shortterm rates to proxy for the expected appreciation term, various measures of the maturity distribution of public debt were added to the regression to capture the effects of changes in asset supplies on the measured risk premium. Their widely-cited results were disappointing, suggesting "that the responsiveness of the rate structure to variations in the age distribution of the national debt outstanding was at best weak...” (p. 587).

Subsequent research on the topic followed the lead of Tobin (1969) in estimating a system of asset demand equations that would allow financial flow variables to affect relative yields, an approach that yielded mixed results. Using a disaggregated analysis of nine sectors and 11 assets, Backus et al. (1980) found relatively small effects of hypothetical debt management operations. Based on their parameter estimates, they 
concluded that $\$ 1$ billion shift between short- and long-term debt (equivalent to a change of six-tenths of one percent of the outstandings as of 1971) would lead to a reduction in the bond yield of only 31/2 basis points. However Friedman (1981) [subsequently published as Part II of Agell et al. (1992)], using methods similar to those of Backus et al. (1980), found evidence of relatively large quantity effects. Friedman's estimates implied a 55 basis point reduction in the 10-year yield in response to a hypothetical cumulative $\$ 4$ billion shift from long-term to short-term debt-roughly four times the magnitude of the Backus et al. (1980) estimates.

Other empirical research employed the Roley (1979) mean-variance optimization framework, calculating the asset demand coefficients directly from the estimated covariance matrix of asset returns. ${ }^{15}$ Frankel (1985) incorporated this framework in jointly estimating the asset demand parameters and the elements on the covariance matrix, but found only “economically insignificant” effects of quantities on relative yields. The generic reason for the small estimated effects from this approach is simply that the returns on bonds of different maturities tend to be highly correlated, and thus close substitutes for one another.

After 20 years of relative neglect, the issue of supply effects on bond yields resurfaced in the context of the 2002-03 “deflation scare”' in the U.S., which, as noted above, rekindled interest in using selective purchases Treasury notes and bonds to bring down long-term interest rates. The most detailed published analysis along these lines is that of Bernanke et al. (2004). That analysis was relatively limited in scope, however, focusing on only very near-term effects during only three specific episodes in 1998, 2000 and 2003. Quantity effects were not estimated directly, but instead inferred by comparing observed yields with the fitted yields from an affine term structure model.

\section{This paper's approach}

The approach in this paper borrows from Fama and Bliss (1987) and Cochrane and Piazzesi (2005) in looking directly at ex post observed term (or risk) premia in the yield curve in an effort to determine whether those premia are forecastable on the basis of

\footnotetext{
${ }^{15}$ Friedman and Kuttner (1992) extended this method to allow for time variation in the covariance matrix of asset returns. Hess (1999), in an approach that also allowed for time variation in the covariance matrix, detected only small effects of quantities on yields in data from the U.K.
} 
currently-available information. The main finding is that Federal Reserve purchases of long-dated bonds also have predictive content for bond term premia—and that its purchases tend to reduce the premia.

Following standard practice in the recent literature on the term structure, the analysis in this paper deals with a hypothetical $n$-period discount bond with price $P^{(n)}$ and (log) yield $y^{(n)}$ equal to $-p^{(n)} / n$, where $p^{(n)}=\ln P^{(n)}$. Working with discount bonds and log yields, it is very easy to write the one-period holding return $r^{(n)}$ in terms of either log prices or log yields

$$
r_{t+1}^{(n)}=p_{t+1}^{(n-1)}-p_{t}^{(n)}=n y_{t}^{(n)}-(n-1) y_{t+1}^{(n-1)} .
$$

The excess one-period holding return $r x^{(n)}$ is then defined as the difference between the one-period holding return and the (known) one-period bond yield, $r x_{t+1}^{(n)}=r_{t+1}^{(n)}-y_{t}^{(1)}$.

The expectations hypothesis of the term structure simply implies that that the expected excess holding return is constant, conditional on information available at time $t$ : $E\left[r x_{t+1}^{(n)} \mid \Omega_{t}\right]=0$. Statistical tests based on this orthogonality condition (or an equivalent expression giving the expected change in a short-term yield as a function of a yield spread) have uniformly and decisively rejected the expectations hypothesis in numerous studies. Fama and Bliss (1987), for example, documented that $n-1$ period ahead oneperiod forward rates (defined as $f_{t}^{(n)}=p_{t}^{(n-1)}-p_{t}^{(n)}$ ) collectively are excellent predictors of holding returns - a finding confirmed (and expanded upon) in recent work by Cochrane and Piazzesi (2005). Of course, any variable dated $t$ or earlier is a potential candidate for inclusion in the information set $\Omega_{t}$. Some recent efforts have attempted to link term premia to macroeconomic developments, as in Ludvigson and $\mathrm{Ng}$ (2005). In this context, this paper's innovation is simply to include variables measuring the composition outstanding government debt, and the composition of the Fed's holdings, as other potential predictors of excess returns or term premia. ${ }^{16}$

The bond data used in the analysis are those described in Fama and Bliss (1987), based on end-of-month price information for all U.S. Treasury securities in the CRSP

\footnotetext{
${ }^{16}$ This approach is more closely related to that of Modigliani and Sutch than it might seem at first glance. If it is assumed that $y^{(n)} \approx y^{(n-1)}$, as would be the case for large $n$, then the expectations hypothesis implies a relationship between $n$-period to 1 -period yield spread and the expected future change in the $n$-period yield; a distributed lag on past 1-period rates is used as an ad hoc proxy for this unobserved expectation.
} 
Treasury file. ${ }^{17}$ From these price data, Fama and Bliss calculate the price of a hypothetical discount bond as the equivalent present discounted value of the income stream associated with a traded coupon bond. ${ }^{18}$ The Fama-Bliss data set includes the prices of discount bonds ranging from one to five years in maturity, for the years 1964 through 2003.

The next data question is which debt measure to use - the Treasury's outstandings, or the Federal Reserve's holdings. Previous efforts to assess the effects of debt management have used the Treasury's outstandings, presumably on the grounds that this is the relevant gauge of supply — and that the Fed's portfolio management should matter only to the extent that it affects the volume of securities in private hands.

This paper's analysis departs from past practice in including both Fed and Treasury variables, thus allowing for the possibility that the effects of the Fed's purchases may differ from changes on the composition of Treasury debt. Endogeneity in the issuance of debt is one reason the effects could differ: to the extent that the Treasury seeks to minimize the cost of borrowing over time, it will tend to issue long-term bonds when their price is relatively high—i.e., with the term premium is low. Thus, optimal debt management on the part of the Treasury could generate a negative correlation between long-term debt issuance and the term premium, which would work in the opposite direction from any supply effects.

The Fed's pattern of security purchases may also be affected by perceived term premia, of course; but the Fed's objective function likely differs from that of the Treasury, and it is probably not exclusively driven by a profit motive. Objectives other than the maximization of expected returns could introduce an element of exogeneity in the SOMA holdings, which could allow the supply effects to be identified.

With these considerations in mind, the regression specification used to assess the effects of debt supplies is

$$
r x_{t+1}^{(n)}=a^{(n)}+\sum_{i=0}^{k} b_{i}^{(n)} m_{t-i}^{F}+\sum_{i=0}^{k} c_{i}^{(n)} m_{t-i}^{T}+\varepsilon_{t+1}^{(n)}
$$

\footnotetext{
${ }^{17}$ This is identical to the data set used by Cochrane and Piazzesi (2005), which is available from Piazzesi's web page.

${ }^{18}$ Alternative methods exist for interpolating and constructing discount bond prices: e.g., McCulloch (1975), Nelson and Siegel (1987), Fisher and Zervos (1995), and Svensson (1995).
} 
where $r x^{(n)}$ is the excess holding return on an $n$-year bond, and $m^{F}$ and $m^{T}$ are variables intended to capture the maturity distribution of Fed holdings and Treasury ouststandings, respectively. The presumption is that the $b_{i}$ coefficients should be negative, so that Fed purchases of long-dated securities would reduce term premia; similarly, positive $c_{i}$ coefficients would indicate that increased Treasury issuance of long-term debt would increase term premia.

In order to accommodate the Treasury debt variables, which are only available quarterly prior to 1975 , the equation is estimated on quarterly data; where monthly data are available, the observation from the last month of each quarter is used. Because $r x^{(n)}$ is a return measured over the span of a full year, the error $\varepsilon^{(n)}$ will follow a movingaverage process. To account for this, the Newey-West correction is used in the calculation of the standard errors.

The remaining detail concerns the specific data to use for the $m^{F}$ and $m^{T}$ variables. Theory provides little guidance on this question; however, as noted by Modigliani and Sutch (1967), the average maturity plotted in Figure 1 is not a particularly good candidate, as it fails to distinguish between changes occurring at the short end of the maturity spectrum from those at the long end. Instead, for the initial set of regressions $m^{F}$ is defined as the change in the share of the Fed's SOMA portfolio held as securities with maturities in excess of five years-i.e., the first difference in the "greater than 5 years" line plotted in Figure 2. The $m^{T}$ variable is defined analogously as the change in the share of outstanding privately-held Federal debt with maturities in excess of five years, i.e., the first difference of the "greater than 5 years" line plotted in Figure 3. The variables are included as first differences in light of the shares' highly persistent (and perhaps even non mean-reverting) behavior. Four lags (i.e., $k=3$ ) are included to allow for some delay and/or persistence in the supply effects.

The key result, reported in Table 2, is that Federal Reserve purchases of long-term debt are associated with highly significant and economically large reductions in term premia. For each maturity, the estimated $b$ parameters are jointly significant at the 0.01 level or better, and the sums of the coefficients are typically three to four times their standard errors. (The individual $b_{i}$ s are themselves less interesting, and left unreported. For each maturity, all are roughly equal in magnitude; the hypothesis that the four are 
equal to one another cannot be rejected.) Moreover, the coefficients are economically significant as well, implying a nontrivial response of yields to shifts in the Fed's portfolio. For example, the sum of the four $b$ parameters for the five-year maturity of 2.27 says that, if the Fed were to increase the share of long-term securities in its portfolio by two percentage points (i.e., exchange $\$ 15$ billion worth of bills for long-dated securities - a large but not atypical change), it would reduce the expected excess one-year return on the five-year note by over four percentage points. ${ }^{19}$ The magnitude of the estimated effects increase with the maturity of the bond, which might be expected since the $m^{F}$ regressor corresponds to the share of bonds with at least five years left to maturity.

Unlike Fed holdings, changes in outstanding publicly-held Treasury debt have small and statistically insignificant effects on term premia. The estimated $c_{i}$ coefficients are positive, as expected; but the magnitudes are much smaller than those of the estimated $b_{i}$ s. They are not statistically significant either individually or jointly; nor are the sum of the coefficients significant. In short, the results for public debt corroborate the findings of Modigliani and Sutch (1967), and others, who reported small effects of asset supplies on relative yields.

The benchmark results in Table 2 are strong - almost too strong. One possible objection is that the SOMA supply variables are, for some reason, correlated with other, omitted variables that are known to forecast excess bond returns. One such set of candidates consists of the implied forward rates from the yield curve, which Fama and Bliss (1987) and Cochrane and Piazzesi (2005) have shown to have a great deal of predictive power for bond term or risk premia. To see whether this might be the case, the Cochrane-Piazzesi forward-rate factor is included in the regression specification (2) in place of the public debt variables:

$$
r x_{t+1}^{(n)}=a^{(n)}+\sum_{i=0}^{k} b_{i}^{(n)} m_{t-i}^{F}+d^{(n)} \gamma^{\prime} \mathbf{f}_{t}+\varepsilon_{t+1}^{(n)},
$$

\footnotetext{
${ }^{19}$ To translate this holding-return effect into an implied impact on relative yields would require an estimate of how the contemplated change in the Fed's holdings would affect expected holding returns, and the oneyear rate, in subsequent periods-information that is not generated by this paper's single-equation reducedform approach. But observing that the yield to maturity is equal to the average of the holding returns over the life of the bond, and conservatively assuming no effects on the holding returns or the one-year rate in subsequent years, a 4 percentage point reduction in the expected holding return on a five-year bond would correspond to an 80 basis point reduction in the 5-year yield, relative to the 1-year rate.
} 
where $\boldsymbol{\gamma}^{\prime} \mathbf{f}_{t}$ is a scalar time series constructed as a weighted average of the current one-year rate one- through four-year-ahead one-year forward rates, with weights $\gamma$ obtained from a regression of the average excess return on the five rates. The results from estimating equation (3) appear in Table 3.

As shown in the table, the inclusion of the $\gamma^{\prime} \mathbf{f}_{t}$ factor as a regressor shrinks the coefficients on the SOMA variables by roughly one-half: the sum of the coefficients for the five-year maturity is now only -1.12 , compared to -2.27 in the specification without the forward rate factor. The effects of SOMA holdings are still quite large in economic terms, however, with a two percentage point (0.02) increase in holdings of long-dated securities reducing the term premium by two percentage points. Moreover, the coefficients remain jointly significant, as is their sum. The forward rate factors is, as in the Cochrane-Piazzesi results, highly significant, with $t$-statistics uniformly in excess of 6. Not surprisingly, the adjusted $R$-squareds are much higher with the inclusion of the forward rate factor - at least 0.40 , compared with 0.10 without.

Another concern might that the results reported in Table 2 and Table 3 might be specific to some specific time period, and thus not robust over the entire sample. In particular, one might worry that the results were unduly influenced by some of the large changes in the composition of the SOMA portfolio occurring during the 1960s: the pronounced 1968-69 maturity "bulge" discussed in the previous section, for example. ${ }^{20}$ To assess the extent to which this could be driving the regression results, the regression equation (3), which includes the Cochrane-Piazzesi factor, was re-run over two distinct subsamples: 1964Q1 through 1975Q4 and 1976Q1 through 2002Q4. The 1976 break date was chosen, somewhat arbitrarily, to correspond approximately to the point at which the composition of the SOMA portfolio stabilized, and began to evolve more gradually than it had in the past.

Table 4 reports the key parameter estimates over the two subsamples. The results indicate that the effects of changes in the SOMA portfolio are considerably larger in the more stable, post-1976 subsample than in the earlier, more volatile period. For the fiveyear note, for example, the sum of the coefficients in the latter period is -3.48 , compared

\footnotetext{
${ }^{20}$ Note that since the Fama-Bliss data begin in 1964, the sample contains only the tail end of Operation Twist.
} 
with -1.12 for the earlier period; the differences for the other maturities are comparable. (Interestingly, the coefficients on the Cochrane-Piazzesi factor are also much larger in the post-1976 sample.) The statistical significance of the SOMA parameter estimates is somewhat weaker, however: in the full sample, and in the pre-1976 subsample, all were jointly significant at the 0.01 level or better; post-1976, the coefficients on the two- and three-year bonds are significant at the 0.05 level, while those for the four- and five-year bonds are only significant at the 0.10 level. The sums of the coefficients remain highly significant, however. Thus, while somewhat weaker in terms of statistical significance in the post-1976 period, the impact of changes in the SOMA portfolio is clearly not an artifact associated with a specific subsample.

Finally, one might wonder whether the results are sensitive to the choice of variables describing the composition of the SOMA portfolio and the Treasury's outstanding debt. In particular, it would be interesting to know whether the Fed's accumulation of securities with maturities in the one- to five-year range had effects on the term premia that were comparable to those of its net purchases of longer-term securities. Similarly, it might be the case that Treasury issuance of securities in the one- to five-year range would have a more pronounced effect on yields than indicated by the result reported in Table 2. To investigate these questions, the regression equation (2) was rerun, using as $m^{F}$ and $m^{T}$ the change in the Fed's holdings of one- to five-year securities (as a share of its total SOMA portfolio), and the change in publicly-held securities in the one- to five-year range (as a share of total outstandings).

The results of this exercise appear in Table 5. Now, neither the Fed portfolio variable nor the Treasury supply variable forecasts excess bond returns. For the SOMA portfolio variables, the estimated sums of the coefficients are statistically insignificant and quantitatively small, compared with those in Table 2 . The estimated sums have the wrong (positive) sign, and the coefficients are not jointly statistically significant. The results also show no significant effect coming from changes in the supply of outstanding one- to five-year Treasuries. With negative adjusted $R$-squareds, the regressions explain virtually none of the variance of bond excess returns. Thus, while the Fed's holdings of securities with maturities in excess of five years seem to be strongly related to ex ante 
term premia, its acquisition of intermediate maturity bonds conveys no comparable information.

\section{Discussion of results}

With four decades of empirical findings suggesting that the impacts on yields of changes in the quantities of Treasuries are small, there is good reason to be skeptical about large estimated effects, like those reported above. The most obvious objectionthat the results are not robust to changes in the sample or the inclusion of other variables — has already been dealt with, at least in a preliminary fashion: that the SOMA debt variables are significant in both subsamples, and survive the inclusion of the forward rate factor, suggests that the results are robust, at least along these two dimensions.

Even so, a puzzling finding is that the Fed's purchases of intermediate-maturity, one- to five-year notes have no discernable effect on the holding returns associated with the two- to five-year securities. A priori, one would have thought that the largest impact of securities purchases would have been for those securities being purchasedconsequently, it seems odd that the Fed's purchases of 10-year notes (say) would have a larger impact on the five-year notes yield than a purchase of five-year notes. A close look at Figure 2 suggests one possible reason for this result. That figure shows that share of the SOMA portfolio invested in securities in the one- to five-year range is highly volatile-considerably more erratic than the share in longer-term issues. Moreover, it appears from the "mirror-image" behavior of the less-than one-year category that much of this volatility comes from the transitioning of issues from the intermediate- to the short-term category: for example, a note with just over 12 months to maturity moving into the less-than-12 month range. Thus, much of the movement in the one- to five-year variable probably reflects measurement error, and not portfolio management.

A deeper concern is that the Fed's purchases of long-term bonds may be endogenous with respect to expected excess returns, and thus not the underlying cause of the observed changes in bond term premia. This conjecture is, of course, hard to refute in the absence of an intentional experiment (e.g., an Operation Twist that actually had a discernable impact on the maturity structure), or failing that, a reliable instrument capturing an exogenous element of Fed securities purchases. 
Still, it is hard to conceive of a scenario in which endogeneity could account for the estimated negative relationship between Fed purchases and term premia. Suppose, for instance, that the manager of the system open market account sought to maximize expected returns: acting in this way, the manager would purchase long-term securities when prices were low, and expected holding returns high. In such a scenario, Fed purchases of long-term bonds would predict higher-than-average returns, rather than the below-average holding returns that, in the data, are associated with increased SOMA holdings. The same would be true if the Fed purchased bonds in (successful) efforts to stabilize bond prices. The opposite might be true, however, if the Fed's efforts along these lines were generally unsuccessful, intervening to no effect during prolonged bond selloffs.

\section{Conclusion}

Can central banks target bond prices? In the end, the answer to the question posed in the title depends on what it means to "target." Clearly, central banks can exert some influence over the long end of the yield curve through their announcements of a likely path for future short-term interest rates. Moreover, the Fed's experience between 1942 and 1951 demonstrates that central banks can, for a time, directly affect long-term rates by offering to buy and sell securities at fixed prices—although this only works so long as the pegged prices are generally consistent with the expected path of future shortterm rates.

The primary focus of this paper has been on the extent to which debt management—broadly defined to include central bank securities purchases as well as government bond issuance — can affect the yield curve, even in the absence of explicit caps or pegs on longer-term rates. The surprising answer suggested by the paper's empirical results is that there is indeed some scope for the Fed to affect yields through its portfolio management decisions. Taken at face value, the results indicate that relatively modest shifts in the Fed's portfolio could have effects on term premia measured in percentage points, rather than basis points-a magnitude considerably in excess of most previous estimates. Of course, it is impossible to rule out the possibility that the estimated relationship is not truly causal, and that the observed negative relationship 
between SOMA purchases and future excess returns reflects some omitted factor jointly affecting term premia and Fed decisionmaking.

Still, the strength of the results suggests that the long-neglected connection between debt management and monetary policy could be a productive area for renewed theoretical and empirical investigation. First, in order to interpret the results presented in this paper, it would be important to understand the objectives driving the Fed's portfolio decisions, and the extent to which the pursuit of these objectives could explain the patterns observed in the data. Second, further exploration of the results' robustness with respect to the inclusion of other predictors, such as macroeconomic factors, would be necessary to establish a definitive link between asset supplies and bond prices. Finally, further work is needed to incorporate supply effects into a more formal asset price framework, such as an affine yield curve model. 
Figure 1: Average maturity of privately-held Treasury debt and the SOMA portfolio

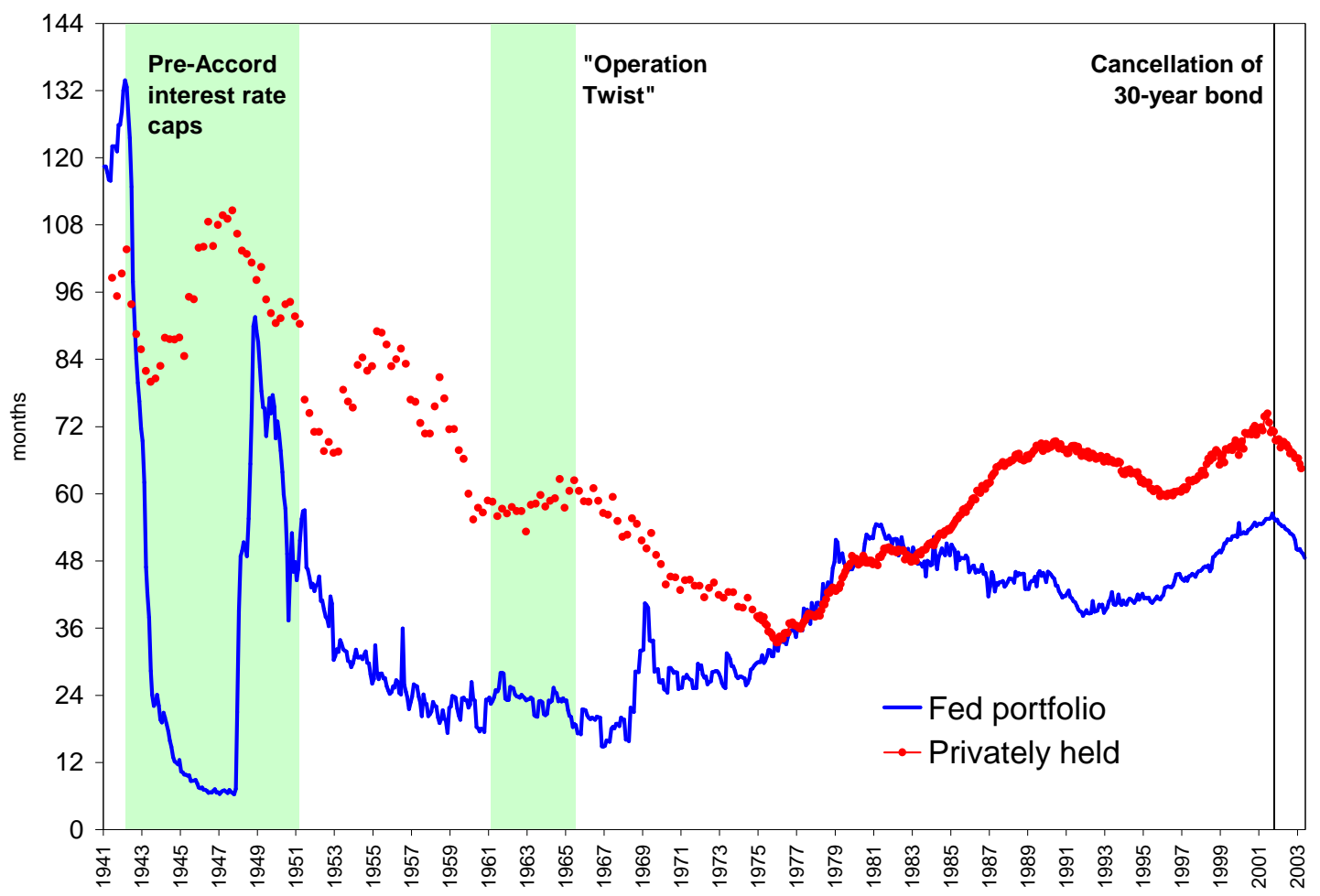

Notes: The Treasury data on the maturity distribution of privately-held public debt are from Table FD-5 of the Treasury Bulletin, and available post-1975 through Haver Analytics; pre-1975 data were obtained from the Federal Reserve's Annual Statistical Digest, and Banking and Monetary Statistics. The maturity distribution of the SOMA portfolio is reported in Table 1.19 of the Statistical Supplement to the Federal Reserve Bulletin. Historical data were obtained from the Federal Reserve's Annual Statistical Digest, and Banking and Monetary Statistics. 
Figure 2: Maturity distribution of the SOMA portfolio

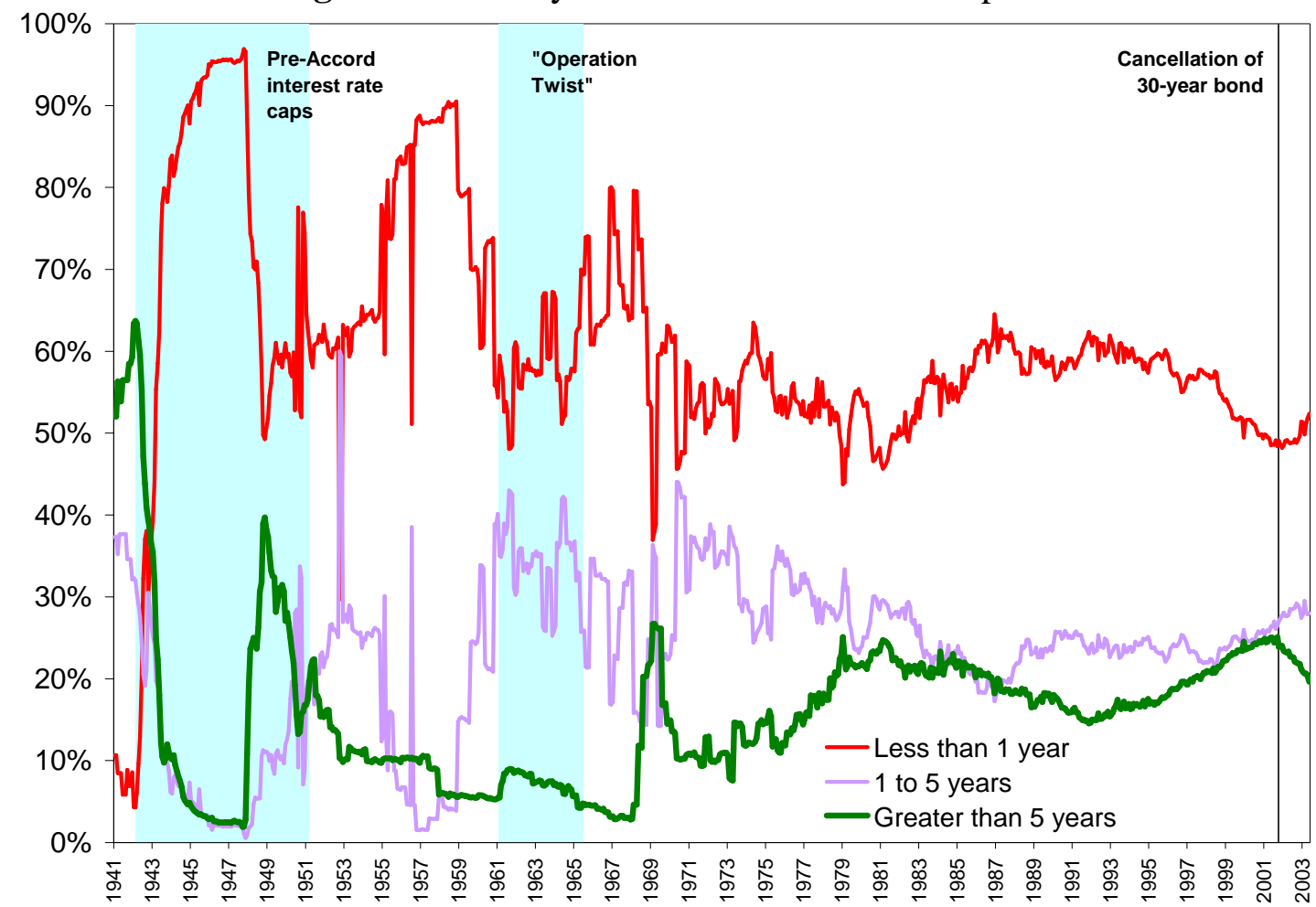

Notes: See notes to Figure 1.

Figure 3: Maturity distribution privately-held Treasury debt

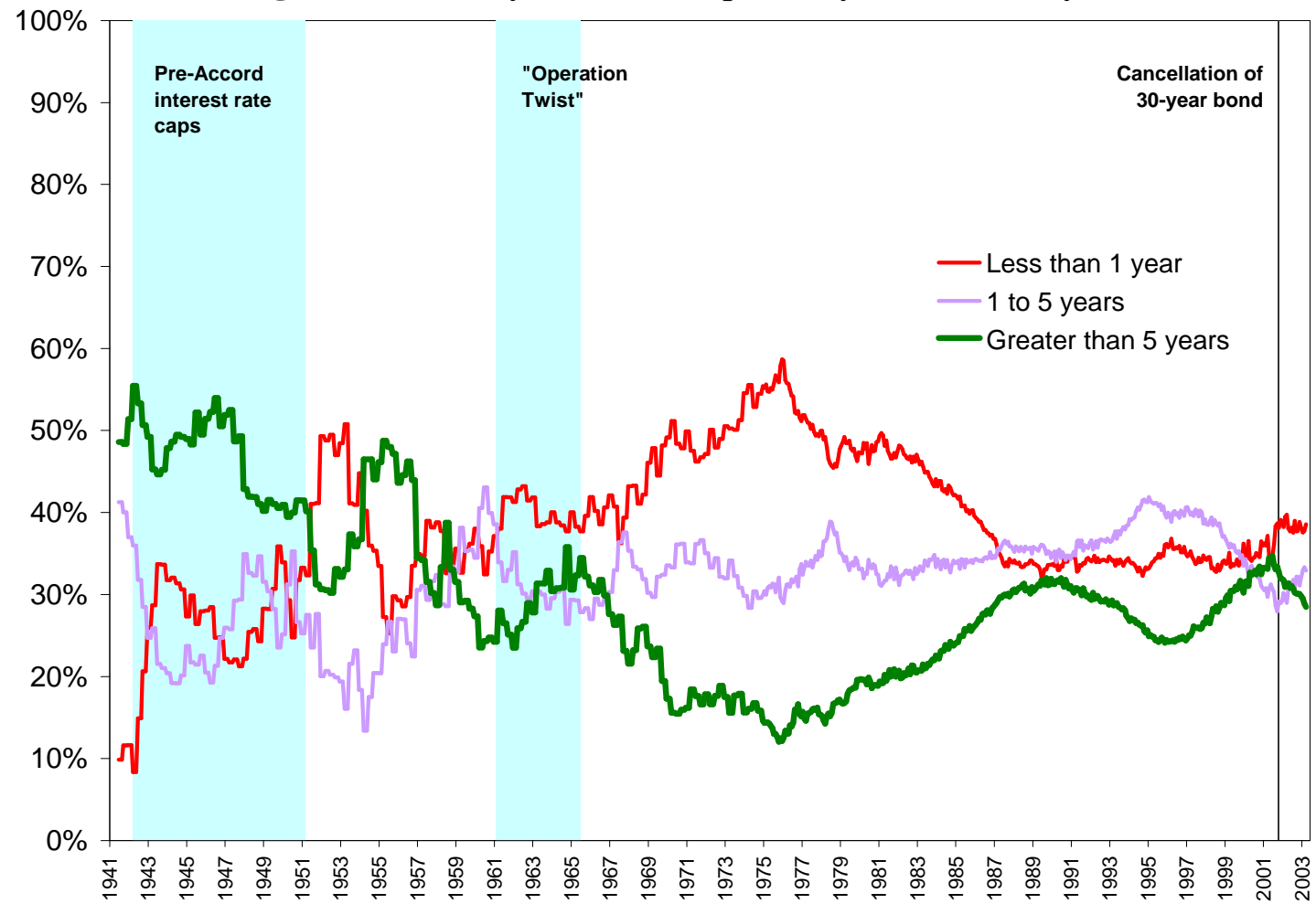

Notes: See notes to Figure 1. 
Figure 4: Outstanding bonds and yields, 1998-2002

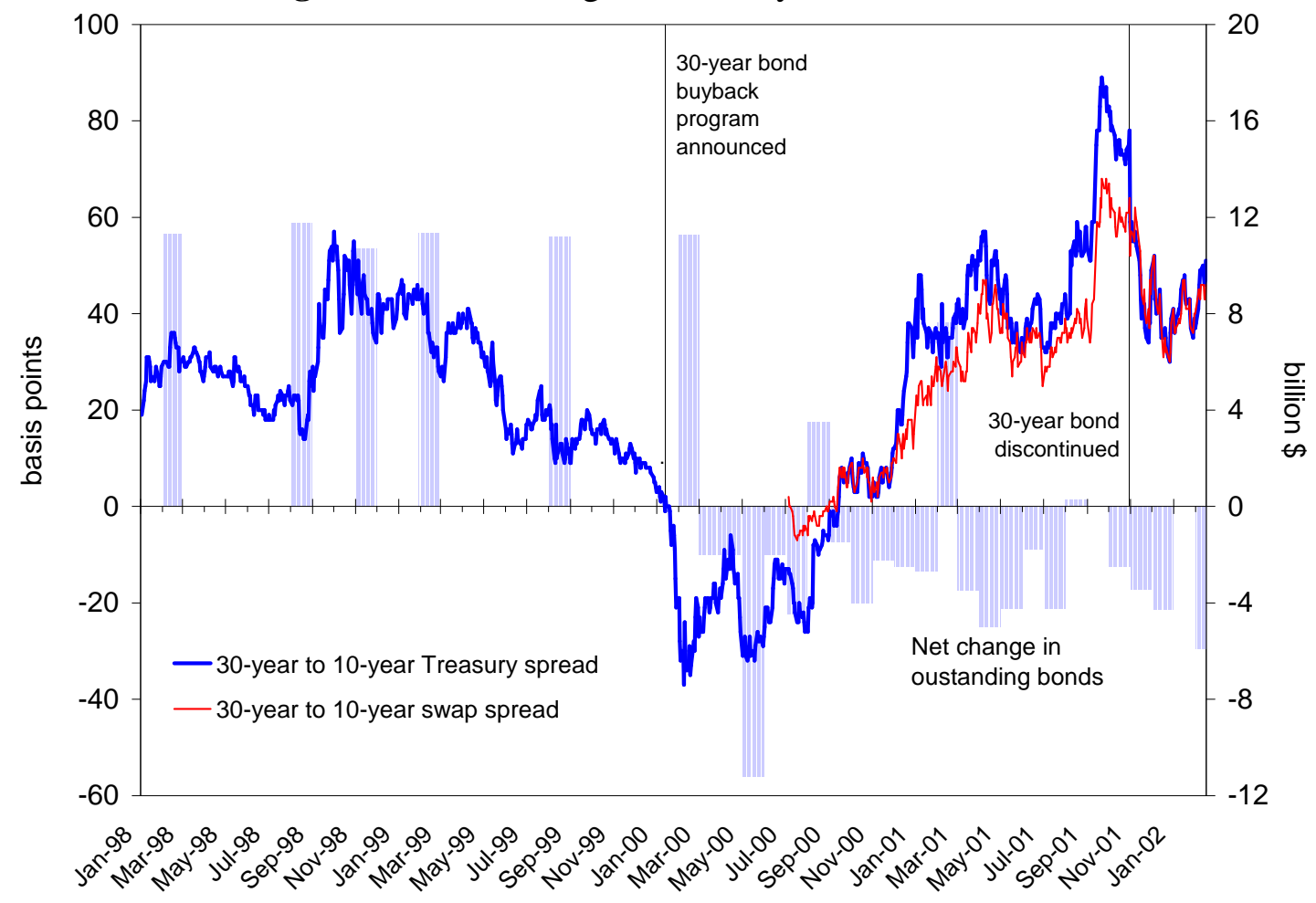

Notes: The Treasury data on outstanding bonds are from Table FD-2 of the Treasury Bulletin, and the interest rate data are from the Federal Reserve's H.15 release. 
Table 1: Volume and composition of Federal debt and the SOMA portfolio

\begin{tabular}{lccccc}
\hline & & \multicolumn{4}{c}{ Maturity } \\
\cline { 3 - 6 } & Total & $<1$ year & $1-5$ years & $5-10$ years & > 10 years \\
\hline $\begin{array}{l}\text { Privately-held Treasury } \\
\text { securities (billions) }\end{array}$ & 3400 & 1177 & 1238 & 535 & 450 \\
$\quad \begin{array}{l}\text { Share of total (\%) } \\
\text { Securities held in SOMA }\end{array}$ & 744 & 400 & 211 & 57 & 77 \\
$\begin{array}{l}\text { account (billions) } \\
\text { Share of SOMA total (\%) }\end{array}$ & & 54 & 28 & 8 & 10 \\
$\begin{array}{l}\text { SOMA share of } \\
\text { outstandings (\%) }\end{array}$ & 18 & 25 & 15 & 10 & 15 \\
\hline
\end{tabular}

Treasury data are from Table FD-5 in the Treasury Bulletin, and Fed data are from Table 1.19 in the statistical supplement to the Federal Reserve Bulletin. Figures are from December 2005. The Fed's holdings are added to the volume of privatelyheld securities in calculating the denominator for the SOMA share of outstandings. 
Table 2: Excess returns and long-maturity bond supply, benchmark results

\begin{tabular}{|c|c|c|c|c|c|c|}
\hline \multirow[b]{2}{*}{ Maturity } & \multirow[b]{2}{*}{ Intercept } & \multicolumn{2}{|c|}{ SOMA variables $\left(m^{F}\right)$} & \multicolumn{2}{|c|}{ Treasury variables $\left(m^{T}\right)$} & \multirow[b]{2}{*}{$\bar{R}^{2}$} \\
\hline & & $\begin{array}{c}\text { Sum of } \\
\text { coefficients }\end{array}$ & $\begin{array}{c}\text { Joint } \\
\text { significance }\end{array}$ & $\begin{array}{c}\text { Sum of } \\
\text { coefficients }\end{array}$ & $\begin{array}{c}\text { Joint } \\
\text { significance }\end{array}$ & \\
\hline 2-year & $\begin{array}{c}0.006 \\
(0.003)\end{array}$ & $\begin{array}{l}-0.73 \\
(0.19)\end{array}$ & $<0.01$ & $\begin{array}{c}0.21 \\
(0.43)\end{array}$ & 0.83 & 0.10 \\
\hline 3-year & $\begin{array}{c}0.009 \\
(0.005)\end{array}$ & $\begin{array}{l}-1.34 \\
(0.34)\end{array}$ & $<0.01$ & $\begin{array}{c}0.19 \\
(0.77)\end{array}$ & 0.92 & 0.11 \\
\hline 4-year & $\begin{array}{c}0.012 \\
(0.007)\end{array}$ & $\begin{array}{l}-1.82 \\
(0.44)\end{array}$ & $<0.01$ & $\begin{array}{c}0.19 \\
(1.07)\end{array}$ & 0.94 & 0.10 \\
\hline 5-year & $\begin{array}{c}0.012 \\
(0.008) \\
\end{array}$ & $\begin{array}{l}-2.27 \\
(0.53) \\
\end{array}$ & $<0.01$ & $\begin{array}{c}0.35 \\
(1.32) \\
\end{array}$ & 0.92 & 0.10 \\
\hline
\end{tabular}

Notes: The sample period is 1964Q1 through 2002Q4 (156 observations). Parentheses contain standard errors, calculated using a Newey-West MA(4) correction.

Table 3: Excess returns and SOMA holdings, including forward rate factor

\begin{tabular}{lcccccc}
\hline & & \multicolumn{2}{c}{ SOMA variables $\left(m^{F}\right)$} & & Cochrane-Piazzesi \\
\cline { 3 - 4 } Maturity & Intercept & $\begin{array}{c}\text { Sum of } \\
\text { coefficients }\end{array}$ & $\begin{array}{c}\text { Joint } \\
\text { significance }\end{array}$ & $\begin{array}{c}\text { Cochard rate factor }\left(\gamma^{\prime} \mathbf{f}\right) \\
\text { forwy }\end{array}$ & $\bar{R}^{2}$ \\
\hline 2-year & 0.002 & -0.36 & $<0.01$ & 0.40 & 0.41 \\
& $(0.002)$ & $(0.15)$ & & $(0.06)$ & \\
3-year & 0.002 & -0.68 & $<0.01$ & 0.78 & 0.44 \\
& $(0.003)$ & $(0.26)$ & & $(0.10)$ & \\
4-year & 0.002 & -0.88 & $<0.01$ & 1.13 & 0.46 \\
& $(0.004)$ & $(0.34)$ & & $(0.14)$ & \\
5-year & 0.001 & -1.12 & $<0.01$ & 1.36 & 0.44 \\
& $(0.005)$ & $(0.40)$ & & $(0.17)$ & 0.44 \\
\hline
\end{tabular}

Notes: The sample period is 1964Q1 through 2002Q4 (156 observations). Parentheses contain standard errors, calculated using a Newey-West MA(4) correction. 
Table 4: Subsample stability

\begin{tabular}{|c|c|c|c|c|c|c|}
\hline \multirow[b]{3}{*}{ Maturity } & \multicolumn{3}{|c|}{ Sample: 1964-1975 } & \multicolumn{3}{|c|}{ Sample: 1976-2002 } \\
\hline & \multicolumn{2}{|c|}{ SOMA variables $\left(m^{F}\right)$} & \multirow{2}{*}{$\begin{array}{l}\text { C-P } \\
\text { factor } \\
\left(\gamma^{\prime} \mathbf{f}\right)\end{array}$} & \multicolumn{2}{|c|}{ SOMA variables $\left(m^{F}\right)$} & \multirow{2}{*}{$\begin{array}{l}\text { C-P } \\
\text { factor } \\
\left(\gamma^{\prime} \mathbf{f}\right)\end{array}$} \\
\hline & $\begin{array}{c}\text { Sum of } \\
\text { coefficients }\end{array}$ & $\begin{array}{c}\text { Joint } \\
\text { significance }\end{array}$ & & $\begin{array}{c}\text { Sum of } \\
\text { coefficients }\end{array}$ & $\begin{array}{c}\text { Joint } \\
\text { significance }\end{array}$ & \\
\hline 2 -year & $\begin{array}{l}-0.32 \\
(0.13)\end{array}$ & $<0.01$ & $\begin{array}{c}0.22 \\
(0.10)\end{array}$ & $\begin{array}{l}-1.45 \\
(0.48)\end{array}$ & 0.03 & $\begin{array}{c}0.38 \\
(0.08)\end{array}$ \\
\hline 3-year & $\begin{array}{l}-0.61 \\
(0.19)\end{array}$ & $<0.01$ & $\begin{array}{c}0.45 \\
(0.13)\end{array}$ & $\begin{array}{l}-2.48 \\
(0.88)\end{array}$ & 0.03 & $\begin{array}{c}0.77 \\
(0.11)\end{array}$ \\
\hline 4-year & $\begin{array}{l}-0.92 \\
(0.27)\end{array}$ & $<0.01$ & $\begin{array}{c}0.54 \\
(0.18)\end{array}$ & $\begin{array}{l}-3.00 \\
(1.19)\end{array}$ & 0.07 & $\begin{array}{c}1.16 \\
(0.18)\end{array}$ \\
\hline 5-year & $\begin{array}{l}-1.15 \\
(0.31)\end{array}$ & $<0.01$ & $\begin{array}{c}0.71 \\
(0.21) \\
\end{array}$ & $\begin{array}{l}-3.48 \\
(1.45)\end{array}$ & 0.10 & $\begin{array}{c}1.38 \\
(0.22) \\
\end{array}$ \\
\hline
\end{tabular}

Notes: Parentheses contain standard errors, calculated using a Newey-West MA(4) correction.

Table 5: Excess returns and medium-maturity bond supply

\begin{tabular}{|c|c|c|c|c|c|c|}
\hline \multirow[b]{2}{*}{ Maturity } & \multirow[b]{2}{*}{ Intercept } & \multicolumn{2}{|c|}{ SOMA variables $\left(m^{F}\right)$} & \multicolumn{2}{|c|}{ Treasury variables $\left(m^{T}\right)$} & \multirow[b]{2}{*}{$\bar{R}^{2}$} \\
\hline & & $\begin{array}{c}\text { Sum of } \\
\text { coefficients }\end{array}$ & $\begin{array}{c}\text { Joint } \\
\text { significance }\end{array}$ & $\begin{array}{c}\text { Sum of } \\
\text { coefficients }\end{array}$ & $\begin{array}{c}\text { Joint } \\
\text { significance }\end{array}$ & \\
\hline 2-year & $\begin{array}{c}0.005 \\
(0.003)\end{array}$ & $\begin{array}{c}0.17 \\
(0.10)\end{array}$ & 0.46 & $\begin{array}{c}0.09 \\
(0.41)\end{array}$ & 0.46 & -0.01 \\
\hline 3-year & $\begin{array}{c}0.008 \\
(0.005)\end{array}$ & $\begin{array}{c}0.33 \\
(0.17)\end{array}$ & 0.35 & $\begin{array}{c}0.33 \\
(0.72)\end{array}$ & 0.43 & -0.01 \\
\hline 4-year & $\begin{array}{c}0.010 \\
(0.007)\end{array}$ & $\begin{array}{c}0.45 \\
(0.24)\end{array}$ & 0.40 & $\begin{array}{c}0.65 \\
(0.98)\end{array}$ & 0.43 & -0.01 \\
\hline 5-year & $\begin{array}{c}0.010 \\
(0.009)\end{array}$ & $\begin{array}{c}0.56 \\
(0.29)\end{array}$ & 0.40 & $\begin{array}{c}0.95 \\
(1.20)\end{array}$ & 0.41 & -0.01 \\
\hline
\end{tabular}

Notes: The sample period is 1964Q1 through 2002Q4 (156 observations). Parentheses contain standard errors, calculated using a Newey-West MA(4) correction. 


\section{References}

Agell, J., M. Persson and B. M. Friedman (1992). Does Debt Management Matter?, Oxford University Press.

Andrés, J., J. D. Lópes-Salido and E. Nelson (2004). “Tobin’s Imperfect Asset Substitution in Optimizing General Equilibrium.” Journal of Money, Credit and Banking 36(4): 665690.

Baba, N., S. Nishioka, N. Oda, M. Shirakawa, K. Ueda and H. Ugai (2005). “Japan’s Deflation, Problems in the Financial System, and Monetary Policy.” Monetary and Economic Studies 23(1): 47-112.

Backus, D., W. C. Brainard, G. Smith and J. Tobin (1980). “A Model of U.S. Financial and Nonfinancial Economic Behavior.” Journal of Money, Credit and Banking 12(2): 259293.

Bernanke, B. S. (2002). Making Sure 'It’ Doesn't Happen Here, Board of Governors of the Federal Reserve System.

Bernanke, B. S., V. R. Reinhart and B. P. Sack (2004). "Monetary Policy Alternatives at the Zero Bound: An Empirical Assessment.” Brookings Papers on Economic Activity 2004(2): 1-78.

Black, F. (1995). “Interest Rates as Options.” Journal of Finance 50(7): 1371-1376.

Bremner, R. P. (2004). Chairman of the Fed. New Haven, Yale University Press.

Chandler, L. (1949). "Federal Reserve Policy and Federal Debt.” American Economic Review 39: 405-429.

Christiano, L. J. (2000). “Comment on 'Theoretical Analysis Regarding a Zero Lower Bound on Nominal Interest Rates’.” Journal of Money, Credit and Banking 32(4): 905-930.

Cochrane, J. H. and M. Piazzesi (2005). “Bond Risk Premia.” American Economic Review 95(1): 138-160.

Eggertsson, G. and M. Woodford (2003). "The Zero Bound on Interest Rates and Optimal Monetary Policy.” Brookings Papers on Economic Activity 2003(1): 139-211.

Eichengreen, B. and P. M. Garber (1991). Before the Accord: U.S. Monetary-Fiscal Policy, 1945-51. Financial Markets and Financial Crises. R. G. Hubbard. Chicago, University of Chicago Press for the National Bureau of Economic Research.

Fama, E. F. and R. R. Bliss (1987). "The Information in Long-Maturity Forward Rates.” American Economic Review 77(4): 680-692. 
Fisher, M. and D. Zervos (1995). Fitting the term structure of interest rates with smoothing splines Board of Governors of the Federal Reserve System.

Frankel, J. A. (1985). “Portfolio Effects, Empirically Estimated.” Quarterly Journal of Economics 100(Supplement): 1041-1065.

Friedman, B. M. (1981). Debt Management Policy, Interest Rates, and Economic Activity, National Bureau of Economic Research.

Friedman, B. M. (2003). "Comments on 'The Zero Bound on Interest Rates and Optimal Monetary Policy’” Brookings Papers on Economic Activity 2003(1): 212.

Friedman, B. M. and K. N. Kuttner (1992). “Time-Varying Risk Perceptions and the Pricing of Risky Assets.” Oxford Economic Papers 44(4): 566-598.

Friedman, B. M. and V. V. Roley (1987). Aspects of Investors’ Behavior Under Risk. Arrow and the Ascent of Modern Economic Theory. G. R. Feiwel. New York, New York University Press.

Fujiki, H. and S. Shiratsuka (2002). "Policy duration effect under the zero interest rate policy in 1999-2000: Evidence from Japan's money market data.” Monetary and Economic Studies 20(1): 1-31.

Hays, K. (2003). “A messy Fed divorce.” CNN Money, August 12, http://money.cnn.com/2003/08/12/commentary/column_hays/fed-hays/index.htm.

Hess, G. D. (1999). The maturity structure of government debt and asset substitutability in the United Kingdom. Government debt structure and monetary conditions. K. A. Chrystal. London, Bank of England: 131-155.

Lucas, R. E., Jr. (1978). “Asset Prices in an Exchange Economy.” Econometrica 46(6): 14291445.

Ludvigson, S. and S. Ng (2005). Macro Factors in Bond Risk Premia, National Bureau of Economic Research.

McCallum, B. T. (2000). “Theoretical Analysis Regarding a Zero Lower Bound on Nominal Interest Rates.” Journal of Money, Credit and Banking 32(4): 870-904.

McCulloch, J. H. (1975). “An Estimate of the Liquidity Premium.” Journal of Political Economy 83: 95-113.

Meltzer, A. (2004). A History of the Federal Reserve, Vol. 1: 1913-1951. Chicago, University of Chicago Press.

Modigliani, F. and R. Sutch (1966). “Innovations in Interest Rate Policy.” American Economic Review 56(1): 178-197. 
Modigliani, F. and R. Sutch (1967). "Debt Management and the Term Structure of Interest Rates: An Empirical Analysis of Recent Experience.” Journal of Political Economy 75(4): 569-589.

Nelson, C. R. and A. F. Siegel (1987). “Parsimonious Modeling of Yield Curves.” Journal of Business 60(4): 473-489.

Okina, K. and S. Shiratsuka (2004). "Policy Commitment and Expectation Formation: Japan's Experience under Zero Interest Rates.” North American Journal of Economics and Finance 15(1): 75-100.

Orphanides, A. and V. Wieland (2000). "Efficient monetary policy design near price stability.” Journal of the Japanese and International Economies 14: 327-365.

Roley, V. V. (1979). “A Theory of Federal Debt Management.” American Economic Review 69: $915-925$.

Rolph, E. R. (1957). “Principles of Debt Management.” American Economic Review 47(3): 302-320.

Svensson, L. E. O. (1995). "Estimating and Interpreting Forward Interest Rates: Sweden 1992-1994.” Sveriges Riksbank Quarterly Review 1995 3: 13-26.

Svensson, L. E. O. (2003). “Escaping from a Liquidity Trap and Others: The Foolproof Way and Others.” Journal of Economic Perspectives 17(4): 145-166.

Tobin, J. (1963). An Essay on Principles of Debt Management. Commission on Money and Credit. Englewood Cliffs, NJ, Prentice-Hall: 143-218.

Tobin, J. (1969). “A General Equilibrium Approach to Monetary Theory.” Journal of Money, Credit and Banking 1: 15-29.

Tobin, J. (1972). The New Economics One Decade Older Princeton, NJ, Princeton University Press.

Toma, M. (1992). “Interest Rate Controls: The United States in the 1940s.” Journal of Economic History 52: 631-650.

Volcker, P. A. (2002). “Monetary Policy Transmission: Past and Future Challenges.” Federal Reserve Bank of New York Economic Policy Review 8(1): 7-14.

Walker, C. E. (1954). "Federal Reserve Policy and the Structure of Interest Rates on Government Securities.” Quarterly Journal of Economics 67: 19-42.

Wicker, E. R. (1969). “The World War II Policy of Fixing a Pattern of Interest Rates.” Journal of Finance 24: 447-458. 